\title{
Assessing Noise Pollution and its Impact on Student's Blood Pressure and Their Learning Performance in Palestine
}

\author{
Muralia Hustim ${ }^{1, *}$, Alaa El Zaza² ${ }^{2}$ Wesam Al Madhoun ${ }^{3}$, Ziad Abu Heen $^{2}$, S Hamid Aly ${ }^{1}$, \\ and Muhammad Isran Ramli ${ }^{1}$ \\ ${ }^{1}$ Department of Environmental Engineering, Universitas Hasanuddin, Indonesia \\ ${ }^{2}$ Environment and Earth Science Department, The Islamic University of Gaza, Palestine \\ ${ }^{3}$ Department of Civil and Environmental Engineering, Universiti Teknologi Petronas, Malaysia
}

\begin{abstract}
The aim of this research was to assess noise pollution trends and to examine the relationship between noise levels and blood pressure (systolic and diastolic), pulse rate and the students' performance at several Palestinian preparatory and secondary schools. Noise levels were monitored at 41 preparatory and secondary schools in Gaza, Palestine. Trends were compared among schools and with the world health organization (WHO) standards as well. Student's blood pressure (systolic and diastolic) and pulse rate were recorded for (432) students, (184 male 1248 female). The readings were taken before and after exposure to noise at schools' environment for at least four hours, where the age of these students were between (13-17) years. In order to investigate the effect of noise on the student's blood pressure, pulse rate and performance, an experiment was conducted on two groups of students, the first was controlled group and the second was trial. In this study, two devices were used, the sound level meter, and the mercurial pressure device. T-test was performed to investigate correlation among the variables. The results show that the noise levels range from 49.0 to $67.5 \mathrm{~dB}$, where Bashir Rayes Secondary Girls School had the highest level of noise while Kafr Qasim Secondary Girls School had the lowest level of noise. The results showed also that there is a positive correlation between noise exposure and the students blood pressure, pulse rate and achievement.
\end{abstract}

\section{INTRODUCTION}

Noise, defined as 'unwanted sound', is perceived as an environmental stressor and nuisance (Matheson, 2003), typically it is characterized by the intensity, frequency, periodicity

\footnotetext{
* Corresponding author: muraliahustim@yahoo.com
} 
(continuous or intermittent) and duration of sound. Sound is the result of pressure changes in the air caused by vibration (Basrur, 2000). Noise is considered to be an environmental challenge in schools today because it causes annoyance and impairs communication and learning (Dockrell, 2004).

However, the harmful effects of noise in general are not fully understood, WHO (2011), reported cardiovascular disease, cognitive, impairment, sleep disturbance, tinnitus and annoyance as effects that noise exerts on heath. Its estimated that at least one million healthy life years are lost every year due to traffic related noise in western Europe (Dockrell, 2003). Exposure to excessive noise is a major cause of hearing disorders worldwide; $16 \%$ of the disabling hearing loss in adults is attributed to occupational noise, ranging from $7 \%$ to $21 \%$ in the various sub-regions (Nandi \& Dhatrak,2008).

In order to better counteract noise induced hearing loss, European directive which took effect in February 2006, established the minimal safety level at the equivalent noise exposure limit to $80 \mathrm{~dB}(\mathrm{~A})$ (Education, 2012). The motive to investigate the impact of noise on students because they are more susceptible than adults (Basrur, 2000). In most countries, noise regulations suggest that the maximum outdoor noise level for educational buildings should be $55 \mathrm{dBA}$ (1Aeq). Levels beyond $55 \mathrm{dBAl}$ (1Aeq) at outdoor will cause a decrease in educational efficiency (Enmarker, 2004).

Nowadays noise pollution is common in Gaza, where it comes from different sources such as traffic and power generators which could affect the Gazans life quality. Education wise, there are many factors that affect the student's achievement and blood pressure. Firstly, the location of the school (on main streets or near markets); secondly, the high density of students in classrooms and thirdly, the educational activities in classrooms. Lastly, the location of the playgrounds if its very close to the classrooms. The previous sources cause high levels of noise, consequently create negative impacts on students. This challenging situation urges researchers to investigate noise in order to find out the trends of noise, its potential impacts and to propose coping mechanism.

In the current research, schools in west Gaza were classified according to noise levels then the effect of high noise on the student's achievement and blood pressure were investigated. The aims of this study were, to investigate the relationship between environmental noise levels and the student's achievement in West Gaza secondary schools, and to examine the impacts of noise on the student's blood pressure.

\section{MATERIAL AND METHODS}

\section{Methodology}

A field study to monitor noise in all schools of West Gaza was conducted and the measurements were classified into high noise schools and low noise. A representative sample from the two categories was selected, blood pressure and pulse were examined and the student's achievement of both categories was assessed. Moreover, two samples, a control group sample and an experimental sample were tested, in order to confirm the extent of the impact of noise on the students' achievement and blood pressure and pulse rate.

\section{Geographic Context}

Gaza strip is divided into seven educational areas as follows: (East Gaza, West Gaza, North Gaza, Middle area, Khan Yonis, East Khan Yonis and Rafah). The number of schools in Gaza governorates are (693) school, ministry of Education and Higher Education supervises 398 schools, 245 school are supervised by The United Nations Relief and Works Agency 
for Palestine Refugees in the Near East (UNRWA) and 50 schools are supervised by the private sector. There are 468,653 students in Gaza strip for the current academic year, 228,076 study at the government al schools, 224,795 students are registered in the UNRWA schools and 15,782 students are enrolled in private schools.

\section{Site Selection}

In this study, the governmental schools in the West Gaza directorate were selected, which oversees 82 schools which are $20 \%$ of governmental schools. The number of the students in the governmental schools were 47850 students, 32624 were at the preparatory schools and 15226 were at the secondary schools. The map in figure 1 shows the study location. The present study has conducted a road traffic noise (RTN) which consist of noise level, traffic volume, and vehicle speed. The survey located at 40 roadsides in Makassar City, Indonesia. Table 1 presents the characteristics of the roads such as length, lane, width, and the distance between the point measurement of the noise level measurement and the centerline of the roads.

\section{Study Sample}

The study sample included 41 schools out of 82 government schools in West Gaza Directorate. Thirty-three schools (out of 82) were excluded because the age of the students is between six and twelve years, where it's difficult to examine their blood pressure and achievement. Furthermore two secondary schools were excluded because their students are deaf.

\section{Instruments}

The student's blood pressure (systolic and diastolic) were measured using Blood Pressure Monitor (Bokank Instrument co . ltd. Model mercurial sphygmomanometer Model No: BK1001 Min) as shown in Figure 2, which has a measuring range of $0 \mathrm{mmHg}$ to $300 \mathrm{mmHg}$ . The Capillary was $3.5 \mathrm{~mm} \pm 0.1$. (instruction for Desk-Model-MercurialSphygmomanometer-BK1001,2011). While the pulse rate was measured manually.

The Sound Level Meter which shown in Figure 3, was used to monitor ambient noise levels. It is designed to approximate the loudness level sensitivity of the human ear. It gives objective, reproducible measurements for the sound pressure level. The microphone (1/2 inch Electret condenser) changes the sound to an equivalent electrical signal, which differs in with the acoustical signal. The noise levels were measured using the Auto Ranging type BI- Ds-102, integrating and logging sound level meter, in (dB) units with an accuracy of \pm $1.5 \mathrm{~dB}$ ( ref $94 \mathrm{~dB} @ 1 \mathrm{KHz}$ ) Resolution: $0.1 \mathrm{~dB}$ and with $10 \mathrm{mV} / \mathrm{dB}$, impedance approx. 100 ohm and its dynamic range is 50dB (Instruction for Sound Level Meter, 2010).

\section{Noise Monitoring}

Schools basic data (number of students, location and design) were collated, filed visit was conducted before start the noise monitoring campaign. Noise levels were measured at different points of the schools, three readings were recorded at each floor and readings were averaged. Finally, the schools were classified to noisy and quiet according to noise standards. 


\section{Blood Pressure Examination}

The study population was selected based on the statistical software Epi. Info.7, it was chosen from eight government schools in west Gaza as follows:

Students were selected from the highest and lowest readings of noise levels in male and female secondary and preparatory schools, 484 students were chosen from these schools. Their blood pressure and pulse rate were measured twice a day, the first one was at 7:15 am before starting the lessons and the second was after 4-5 hours from staying in school. In addition, the results of the students in the final exam were noted to investigate if there is any relation between noise levels and students' performance (average), pulse rate and blood pressure.

\section{Noise and Students Achievements}

Forty female students from the same level of achievement $(85 \%-90 \%)$ were selected as an experimental sample, taking into account the social and environmental conditions. Firstly, the blood pressure and pulse rate were examined, followed by explanation of a lesson on" Nitrogen Cycle in Nature" by the same teacher. Then the students were divided into two groups each of them contains 20 to provide them with unified exam. The first group answered the exam in a quiet environment where the noise level was $45 \mathrm{~dB}$ or less, after that blood pressure and pulse rate were measured. The second group of students answered the exam in a noisy environment where noise level was $73 \mathrm{~dB}$ or plus, then their blood pressure and pulse were examined. Finally, the students results were analyzed and compared to investigate the relationships among noise level, student achievement, their pulse rate and blood pressure.

\section{RESULTS AND DISCUSSION}

\section{Field Visit}

The following data were collected during the field visits to the preparatory and secondary schools at West Gaza throughout the study durations, these schools were classified according to gender, $47 \%$ of the schools were males and $53 \%$ were female schools. Secondly, the schools were divided according to the class density, school level and location, as shown in table (1).

It can be found in the fluctuations of noise levels, LAeq, LA05, LA50, and LA95 for 10 minutes from 8 a.m. to 5 p.m. that noise levels are almost constant through the measurement times ( 8 a.m. to 5 p.m.); the difference between ten LAeq $\mathrm{s}$ during the measurement hours is within $3 \mathrm{~dB}$ in all roads. In further, 40 data of LAeq,day for each road are within $68 \mathrm{~dB}$ and $77 \mathrm{~dB}$, and the arithmetic average of them is $73 \mathrm{~dB}$. This shows that all the areas along the surveyed roads are very noisy, and if the Environmental Quality Standard for Noise in Indonesia shall be applied, more than $90 \%$ of the areas exceed the standard even though the highest value of the Standard $(70 \mathrm{~dB})$ is adopted.

Table 1 Schools Characteristics

\begin{tabular}{|l|l|l|}
\hline & Variables & Average \\
\hline School Division & Preparatory & 49 \\
\hline & Secondary & 51 \\
\hline School location & Main Street & 55 \\
\hline
\end{tabular}




\begin{tabular}{|l|l|l|}
\hline Density of class & Minor Streets & 45 \\
\hline & $20-30$ & 6.4 \\
\hline $31-40$ & 76.6 \\
\hline & $41-50$ & 17 \\
\hline
\end{tabular}

The field survey results show that $49 \%$ of the schools were preparatory and $51 \%$ were secondary, moreover; $55 \%$ of the schools were located nearby main streets and $45 \%$ were on minor streets. In terms of classrooms density $6.4 \%$ of the schools had $20-30$ students in the class, 76.6 \% had 31-40 students in the class and there were $17 \%$ which had 41-50 students. This shows that the schools buildings in west Gaza were not enough, where there were 55 buildings for 82 schools which accommodated 47850 students.

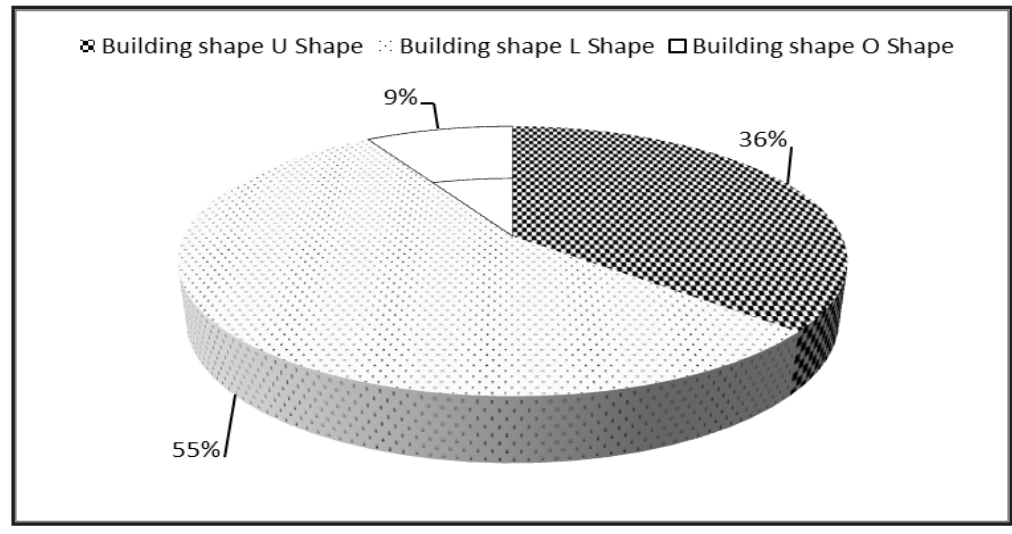

Figure 4 Classifications of schools according to Buildings Shape

Most of the schools (31.9\%) were located in Al-Remal area, which is the middle of west Gaza and its classified as overpopulated area. On the other hand, Al Sahaba area contains only $2.1 \%$ of the West Gaza schools. Shape wise, the school buildings were classified into (U) shaped with 36\%, (L) shaped with $55 \%$ and ( O ) shaped close buildings with $9 \%$.

The schools were operated on two shifts, where $72.3 \%$ of the schools were at the morning shift and $27.6 \%$ were at the afternoon shift, it was reported that there were three (3) secondary schools in the afternoon shift while twenty-one (21) schools were in the morning shift. In the preparatory schools, 7 was in the afternoon shift while the other 18 schools were in the morning shift.

It was observed that the glass of classrooms windows at several schools were smashed, consequently more outdoor noise will impact classrooms environment. Moreover, majority of the classrooms were crowded with student where $76.5 \%$ from these schools had 31 to 40 students in the classroom. This large number of students inside classrooms increases the possibility of causing indoor noise, especially; the dialogues among students and the educational process sounds.

\section{Noise Monitoring}

The noise measurements average in different areas inside and outside the female preparatory schools shown in table 2. The highest noise level was in Fahmi Al-Jerjawi "A" with 61.4 $\mathrm{dB}$ and the lowest was at Hassan Salameh " $\mathrm{A}$ " with an average of $56.2 \mathrm{~dB}$. While the highest noise level in preparatory boys schools was at $\mathrm{Al}$ Yarmouk "B" with $66 \mathrm{~dB}$ and the lowest level was at Anas Ibn Malik "A" school with $58.8 \mathrm{~dB}$. 
Table 2 Summary of Average Noise Levels

\begin{tabular}{|c|c|c|c|c|}
\hline No. & Name (Female) & $\begin{array}{l}\text { Noise level } \\
\text { (dB) }\end{array}$ & Name (Male) & $\begin{array}{c}\text { Noise } \\
\text { level (dB) }\end{array}$ \\
\hline \multicolumn{5}{|c|}{ Primary } \\
\hline 1. & Hassan Salameh "A" & 56.2 & AnasIbn Malik “A” & 58.8 \\
\hline 2. & Al SaydaRoqya & 56.7 & Al Neel & 60.3 \\
\hline 3. & Al Shareqa "B" & 56.8 & Al Yarmouk "A" & 60.7 \\
\hline 4. & Hamama & 57.4 & Amer Ibn El Aass "B" & 60.9 \\
\hline 5. & $\begin{array}{l}\text { Al Majeda way } \\
\text { IbnAmmar "A" }\end{array}$ & 57.5 & Suleiman Sultan "A" & 61.7 \\
\hline 6. & $\begin{array}{l}\text { Al Majeda way } \\
\text { IbnAmmar "B" }\end{array}$ & 58.3 & Al Sauafeer & 62.5 \\
\hline 7. & Al SheakhEajlean & 59.8 & Sarafand & 62.7 \\
\hline 8. & Mustafa Hafez & 61 & Suleiman Sultan "B" & 63 \\
\hline 9. & Al Shareqa "A" & 61.2 & Asdoud & 64.6 \\
\hline 10 & Fahmi Al-Jerjawi “A” & 61.4 & Al Yarmouk "B" & 66 \\
\hline \multicolumn{5}{|c|}{ Secondary } \\
\hline 11 & KafrKasem & 49 & Khaled Al Alamy & 50 \\
\hline 12 & RamizFakhrea & 51.7 & Abu Thar Al Ghaffari & 52.5 \\
\hline 13 & Shuhada Al Shatti & 53.5 & Zuhair Al Alamiy & 53 \\
\hline 14 & Zahraa Al Madaean "A" & 53.7 & Sami Al Alamiy & 54.3 \\
\hline 15 & Balqees Al Yaman & 55 & Adnan Al Alamiy & 54.6 \\
\hline 16 & Yaser Arafat "A" & 56 & Khalil Al Wazeer & 56.9 \\
\hline 17 & Zahraa Al Madaean "B" & 57 & Jules & 58 \\
\hline 18 & Bashir Al Rayes "B” & 62.4 & Yaser Arafat "B" & 60 \\
\hline 19 & Ahmed Shawki "B" & 65.6 & Palestine & 64.7 \\
\hline 20 & Bashir Al Rayes "A" & 67.5 & Alkarmel & 65.4 \\
\hline
\end{tabular}

Furthermore, the results show that the highest noise level at female secondary schools was at Bashir Al Arayes "A" with $67.5 \mathrm{~dB}$ as shown in table (2), and the lowest noise level was in Kafr Kasem school with $49 \mathrm{~dB}$. However the lowest noise level in secondary boys schools was in Khaled Al Alamy with $50 \mathrm{~dB}$ and the highest noise level was in Alkarmel with $65.4 \mathrm{~dB}$.

Table 3 The Noisy and Quiet Schools According to Gender and Grade

\begin{tabular}{|c|l|l|l|l|}
\hline N. & \multicolumn{1}{|c|}{ School } & \multicolumn{1}{|c|}{ Sex } & school level & Noise Level \\
\hline 1 & Bashir Al Rayes “A” & Female & Secondary & 67.5 \\
\hline 2 & Al Yarmouk “B” & Male & Preparatory & 66 \\
\hline 3 & Alkarmel & Male & Secondary & 65.4 \\
\hline 4 & Fahmi Al-Jerjaoi “A” & Female & Preparatory & 61.4 \\
\hline 5 & Anaslbn Malik “A “" & Male & Preparatory & 58.8 \\
\hline 6 & Hassan Salameh “A” & Female & Preparatory & 56.2 \\
\hline 7 & Khaled Al Alamy & Male & Secondary & 50 \\
\hline 8 & Kafr Kasem & Female & Secondary & 49 \\
\hline
\end{tabular}


After comparing the noise levels among schools which shown in Table 2, the school with highest and lowest levels of noise at both males and females were selected to be the study sample as shown in Table 3 .

Table(3) shows that: firstly, the highest noise rate in secondary girls schools was in Basher Al Rayes " $A$ " with $67.5 \mathrm{~dB}$, because it located between two main streets and it's beside a preparatory school from the north side. While, the lowest noise rate was in Kafr Kasem school with $49 \mathrm{~dB}$, due to its location which is far from main streets. On the other hand, the highest noise rate in secondary boys schools was at Alkarmel school with 65.4 $\mathrm{dB}$, since its located on a main street, and it's near a preparatory school from the north, the building is closed and the class density was high. However, the lowest noise rate was at Khaled Al Alamy Boys school with $50 \mathrm{~dB}$, as it's far from the traffic noise at the main street. The location of the school at roadside is a main factor of noise (Haines et al 2000; Department of Education and Employment 1999; Wernar \& Boike 2001).

It also obvious in Table (3) that, the highest noise rate in preparatory girls schools was in Fahmi Al-Jerjawi "A" with $61.4 \mathrm{~dB}$, because it located on two streets and near workshops. The lowest noise rate in preparatory girl's schools was in Hassan Salameh "A" with $56.2 \mathrm{~dB}$, although the school located on a main street; it was quiet, because the classes were far away from the street and the school area is wide. Al Yarmouk "B" school had the highest noise level of $66 \mathrm{~dB}$ among preparatory boys' schools, as a result of its location on a main street, near a kindergarten and surrounded with two other schools.

While the lowest noise rate among preparatory boys' school was at Anas Ibn Malik " $A$ " with $58.8 \mathrm{~dB}$, where the school is located far from the main street and its very wide. The noise levels which were recorded inside and outside the schools' classrooms were compared with the WHO standards, it was found that the noise levels were higher than the permissible limits. According to WHO standard, the noise level should be $35 \mathrm{~dB}$ inside the classroom and $55 \mathrm{~dB}$ outside. Furthermore, the sound level outside schools should not exceed $60 \mathrm{~dB}$ if its at a road side (nearby main streets) and $40 \mathrm{~dB}$ in the populated areas $40 \mathrm{~dB}$.

The correlation between noise levels, student gender, school level, school location and school shift were investigated. As shown in Table 4, ANOVA results indicate that there was a difference between male and female schools, where the male schools were higher with an average noise level of $60.3 \mathrm{~dB}$ and there was no statistical significance.

Table (4): Correlation Between Noise and Sex, Grade and School Location and shift

\begin{tabular}{|c|c|c|c|c|c|c|}
\hline \multicolumn{2}{|c|}{ Properties } & $\mathbf{N}$ & Means & Standard Deviation & ANOVA & Sig. \\
\hline \multirow[t]{2}{*}{ Sex } & Male & 2 & 60.281 & 4.971 & \multirow[t]{2}{*}{1.546} & \multirow[t]{2}{*}{0.129} \\
\hline & Female & $\begin{array}{l}2 \\
2 \\
5\end{array}$ & 58.290 & 3.846 & & \\
\hline \multirow[t]{2}{*}{ School Division } & Primary & $\begin{array}{l}2 \\
3\end{array}$ & 60.799 & 2.682 & \multirow[t]{2}{*}{2.497} & \multirow[t]{2}{*}{0.016} \\
\hline & Secondary & $\begin{array}{l}2 \\
4\end{array}$ & 57.711 & 5.317 & & \\
\hline \multirow[t]{2}{*}{$\begin{array}{l}\text { School } \\
\text { Location }\end{array}$} & Main & $\begin{array}{l}2 \\
6\end{array}$ & 60.269 & 4.646 & \multirow[t]{2}{*}{1.831} & \multirow[t]{2}{*}{0.074} \\
\hline & Branch & $\begin{array}{l}2 \\
1\end{array}$ & 57.926 & 3.982 & & \\
\hline \multirow[t]{2}{*}{ School Shift } & $\mathrm{AM}$ & $\begin{array}{l}3 \\
4\end{array}$ & 59.011 & 4.892 & \multirow[t]{2}{*}{-0.519} & \multirow[t]{2}{*}{0.606} \\
\hline & PM & $\begin{array}{l}1 \\
3\end{array}$ & 59.774 & 3.230 & & \\
\hline
\end{tabular}


While in terms of schools division, there was a significant difference, which means that the noise levels at the studied preparatory schools were higher than the noise at the secondary schools. It was found that the average noise level in the preparatory boys schools was between 58.8-66 dB. On the other hand, noise levels at the secondary boys schools ranged from 50 to $65.4 \mathrm{~dB}$.

Furthermore, it was found that the noise levels at the preparatory girls schools was between 56.2 to $61.4 \mathrm{~dB}$, while the noise levels at the secondary girls schools ranged from 49 to $67.5 \mathrm{~dB}$. The results of this research agreed with other studies (WHO,1999; Niskar et al 1998; Dockrell \& Shield, 2002).

\section{Pulse Rate, Blood Pressure and the Students Achievement}

The pulse rate, blood pressure and the students achievements were examined for 430 students from the schools mentioned in Table 5. These schools include four schools with high noise level ( 2 for males and 2 for females) and another four schools with low noise level. Both categories (noisy and quiet) were compared for pulse rate, blood pressure and the student achievement.

The schools listed in Table 5, were visited before classes started, the pulse rate, systolic blood pressure and Diastolic blood pressure were examined. Same indicators were tested after four hours of schooling, measurements were reported and analysed to find out the differences.

The results in Table (6) show the differences by gender in pulse rate, blood pressure and students achievement before and after classes. The ANOVA results indicate that there were statistical significant differences between pulse rate, blood pressure and students gender due to physiological difference between genders before classes started (Maranon and Reckelhoff, 2013).

Table (5): Sample Results for Pulse, Blood Pressure and the Student Achievement

\begin{tabular}{|c|c|c|c|}
\hline \multicolumn{2}{|c|}{ Variables } & \multirow{2}{*}{$\begin{array}{c}\text { Frequency } \\
50\end{array}$} & \multirow{2}{*}{$\begin{array}{l}\text { Percent } \\
11.574\end{array}$} \\
\hline \multirow{8}{*}{ Name of School } & Khaled Elalamy & & \\
\hline & Elkarmel & 50 & 11.574 \\
\hline & Hasansalama & 66 & 15.278 \\
\hline & Anas ben malek A & 50 & 11.574 \\
\hline & Basher elrayes $\mathrm{A}$ & 58 & 13.426 \\
\hline & KaferGasem & 65 & 15.046 \\
\hline & Elyarmok B & 34 & 7.870 \\
\hline & FahmeEljerjawy & 59 & 13.657 \\
\hline \multirow{2}{*}{ Sex of the Student } & Male & 184 & 42.593 \\
\hline & Female & 248 & 57.407 \\
\hline \multirow{2}{*}{ Grade of the Student } & Preparatory School & 209 & 48.380 \\
\hline & Secondary School & 223 & 51.620 \\
\hline \multirow{2}{*}{ Noise Level } & Noisy & 201 & 46.528 \\
\hline & Quiet & 231 & 53.472 \\
\hline \multicolumn{2}{|c|}{ Total } & 432 & 100.00 \\
\hline
\end{tabular}


Table (6): Correlation between Pulse, Blood Pressure and the Students achievement of the Student based Gender

\begin{tabular}{|c|c|c|c|c|c|c|}
\hline & Sex & $\mathbf{N}$ & Means & $\begin{array}{l}\text { Standard } \\
\text { Deviation }\end{array}$ & $\begin{array}{c}\text { ANO } \\
\text { VA }\end{array}$ & Sig. \\
\hline \multicolumn{7}{|c|}{ Before Classes } \\
\hline \multirow[t]{2}{*}{ Pulse Rate } & Male & 184 & 74.489 & 10.671 & -5.737 & 0.000 \\
\hline & Female & 248 & 81.641 & 14.192 & & \\
\hline \multirow{2}{*}{$\begin{array}{l}\text { Systolic Blood } \\
\text { Pressure }\end{array}$} & Male & 184 & 112.717 & 14.930 & 2.358 & 0.019 \\
\hline & Female & 248 & 109.476 & 13.502 & & \\
\hline \multirow{2}{*}{$\begin{array}{l}\text { Diastolic Blood } \\
\text { Pressure }\end{array}$} & Male & 184 & 72.120 & 9.786 & 2.348 & 0.019 \\
\hline & Female & 248 & 69.960 & 9.199 & & \\
\hline \multicolumn{7}{|c|}{ After Classes } \\
\hline \multirow[t]{2}{*}{ Pulse Rate } & Male & 184 & 76.902 & 10.866 & -4.139 & 0.000 \\
\hline & Female & 227 & 82.674 & 16.189 & & \\
\hline \multirow{2}{*}{$\begin{array}{l}\text { Systolic Blood } \\
\text { Pressure }\end{array}$} & Male & 184 & 110.598 & 14.379 & 1.748 & 0.081 \\
\hline & Female & 227 & 108.370 & 11.463 & & \\
\hline \multirow{2}{*}{$\begin{array}{l}\text { Diastolic Blood } \\
\text { Pressure }\end{array}$} & Male & 184 & 71.522 & 12.005 & 1.597 & 0.111 \\
\hline & Female & 227 & 69.824 & 9.546 & & \\
\hline \multirow{2}{*}{$\begin{array}{l}\text { The students } \\
\text { achievement }\end{array}$} & Male & 184 & 79.674 & 12.052 & \multirow[t]{2}{*}{-2.585} & \multirow[t]{2}{*}{0.010} \\
\hline & Female & 248 & 82.863 & 13.128 & & \\
\hline
\end{tabular}

Furthermore, The ANOVA results in Table 6 show that after classes ended, only the measured pulse rate of students was significantly different when compared males with females, which may caused by different respond to the physiological stress which agrees with Khaksari et al., (2005). Also there was a significant difference between male and female students in term of marks achievements.

According to this research findings, the blood pressure in males were affected more compared with the females which is in line with the study output of Marwan ,(2013), but in terms of pulse rate, this study revealed that females were affected more than males which was vice versa according to Marwan,(2013).

The findings in Table (7) show the differences by schools stage (Prepartory and Secondary) in pulse, blood pressure and students achievement before classes started and after they ended. The ANOVA analysis clearly shows significant difference at all records of pulse rate, blood pressure and students achievement and this explained by the Physiologic respond differences by ages as stated by Andropoulos, (2011).

Table (7): Pulse, Blood Pressure and The students achievement According to Grade

\begin{tabular}{|c|c|c|c|c|c|c|} 
& $\begin{array}{c}\text { Grade of the } \\
\text { Student }\end{array}$ & $\mathbf{N}$ & Means & $\begin{array}{c}\text { Standa } \\
\text { rd } \\
\text { Deviati } \\
\text { on }\end{array}$ & $\begin{array}{c}\text { ANOV } \\
\text { A }\end{array}$ & Sig. \\
\hline Pulse Before & Preparatory School & 20 & $\mathbf{8 1 . 7 5 1}$ & 13.262 & 4.909 & 0.000 \\
& Secondary School & 22 & 75.637 & 12.623 & & \\
\hline $\begin{array}{c}\text { Systolic Blood } \\
\text { Pressure Before }\end{array}$ & Preparatory School & 20 & 107.990 & 12.777 & -4.136 & 0.000 \\
& Secondary School & 22 & $\mathbf{1 1 3 . 5 4 3}$ & 14.955 & & \\
\hline
\end{tabular}




\begin{tabular}{|c|c|c|c|c|c|c|}
\hline \multirow{2}{*}{$\begin{array}{l}\text { Diastolic Blood } \\
\text { Pressure before }\end{array}$} & Preparatory School & 20 & 69.306 & 9.689 & \multirow[t]{2}{*}{-3.372} & \multirow[t]{2}{*}{0.001} \\
\hline & Secondary School & $\begin{array}{c}22 \\
3\end{array}$ & 72.354 & 9.101 & & \\
\hline \multirow[t]{2}{*}{ Pulse after } & Preparatory School & $\begin{array}{c}20 \\
9\end{array}$ & 83.933 & 15.603 & \multirow[t]{2}{*}{5.741} & \multirow[t]{2}{*}{0.000} \\
\hline & Secondary School & $\begin{array}{c}20 \\
2\end{array}$ & 76.114 & 11.656 & & \\
\hline \multirow[t]{2}{*}{$\begin{array}{l}\text { Systolic Blood } \\
\text { Pressure after }\end{array}$} & Preparatory School & $\begin{array}{c}20 \\
9\end{array}$ & 108.086 & 12.056 & \multirow[t]{2}{*}{-2.059} & \multirow[t]{2}{*}{0.040} \\
\hline & Secondary School & $\begin{array}{c}20 \\
2\end{array}$ & 110.693 & 13.586 & & \\
\hline \multirow[t]{2}{*}{$\begin{array}{l}\text { Diastolic Blood } \\
\text { Pressure after }\end{array}$} & Preparatory school & $\begin{array}{c}20 \\
9\end{array}$ & 68.852 & 10.360 & \multirow[t]{2}{*}{-3.369} & \multirow[t]{2}{*}{0.001} \\
\hline & Secondary School & $\begin{array}{c}20 \\
2\end{array}$ & 72.376 & 10.849 & & \\
\hline \multirow[t]{2}{*}{$\begin{array}{l}\text { The Students } \\
\text { Achievement }\end{array}$} & Preparatory school & $\begin{array}{c}20 \\
9\end{array}$ & 2.722 & 1.404 & \multirow[t]{2}{*}{6.123} & \multirow[t]{2}{*}{0.000} \\
\hline & Secondary School & $\begin{array}{c}22 \\
3\end{array}$ & 2.000 & 1.031 & & \\
\hline
\end{tabular}

Moreover the results in Table 7 show that there is a significant difference between preparatory and secondary schools in terms of students performance which agree with Shield and Dockrell,(2003) that stated noise has an effect on children's achievement's at schools.

The finding of this research agreed with the results of other studies on noise impacts, certainly blood pressure and hypertension where were detected in workers who were exposed to Noise (WHO,1999; Green et al.,1991; Wu et al.,1998; Melamed \&Ribak, 1997; Regecova \&Kellerova,1995). This research is also conforms with studies of (Dawabsha, 2012; Sadeq,2011; Ahmad,2011; Saeed, 2010) which show that blood pressure has a positive correlation with noise exposure.

\section{Experimental Sample}

To confirm the credibility of the previous results , an experiment were conducted, where 40 female students from the same level of academic achievement (students who have a GPA of $85 \%-90 \%$ ) were selected, student's social and environmental conditions were taken into consideration.

Table 8: Pulse Rate, Blood Pressure and Students Achievement for the Experimental Sample

\begin{tabular}{|c|c|c|c|c|c|c|}
\hline \multicolumn{2}{|c|}{ Variables } & $\mathbf{N}$ & Means & Standard & ANOVA & Sig. \\
\hline \multirow{2}{*}{$\begin{array}{l}\text { Pulse before } \\
\text { exam }\end{array}$} & Quiet & 20 & 82.100 & 8.663 & \multirow[t]{2}{*}{0.354} & \multirow[t]{2}{*}{0.725} \\
\hline & Noisy & 21 & 81.143 & 8.633 & & \\
\hline \multirow{2}{*}{$\begin{array}{l}\text { Systolic Blood } \\
\text { Pressure } \\
\text { Before exam }\end{array}$} & Quiet & 20 & 109.000 & 9.679 & \multirow[t]{2}{*}{0.289} & \multirow[t]{2}{*}{0.774} \\
\hline & Noisy & 21 & 108.095 & 10.305 & & \\
\hline \multirow{2}{*}{$\begin{array}{c}\text { Diastolic } \\
\text { Blood } \\
\text { Pressure } \\
\text { Before exam }\end{array}$} & Quiet & 20 & 70.500 & 7.592 & \multirow[t]{2}{*}{0.193} & \multirow[t]{2}{*}{0.848} \\
\hline & Noisy & 21 & 70.000 & 8.944 & & \\
\hline
\end{tabular}




\begin{tabular}{|c|c|c|c|c|c|c|}
\hline \multirow{2}{*}{$\begin{array}{l}\text { Pulse After } \\
\text { exam }\end{array}$} & Quiet & 20 & 85.700 & 6.490 & \multirow[t]{2}{*}{-2.555} & \multirow[t]{2}{*}{0.015} \\
\hline & Noisy & 21 & 91.762 & 8.508 & & \\
\hline \multirow{2}{*}{$\begin{array}{l}\text { Systolic Blood } \\
\text { Pressure After } \\
\text { exam }\end{array}$} & Quiet & 20 & 111.000 & 10.712 & \multirow[t]{2}{*}{-1.849} & \multirow[t]{2}{*}{0.072} \\
\hline & Noisy & 21 & 117.143 & 10.556 & & \\
\hline \multirow{2}{*}{$\begin{array}{c}\text { Diastolic } \\
\text { Blood } \\
\text { Pressure After } \\
\text { exam }\end{array}$} & Quiet & 20 & 68.500 & 8.751 & \multirow[t]{2}{*}{-2.652} & \multirow[t]{2}{*}{0.012} \\
\hline & Noisy & 21 & 75.238 & 7.496 & & \\
\hline \multirow{2}{*}{$\begin{array}{l}\text { The students } \\
\text { achievement } \\
\text { exam }\end{array}$} & Quiet & 20 & 84.500 & 12.763 & \multirow[t]{2}{*}{2.864} & \multirow[t]{2}{*}{0.007} \\
\hline & Noisy & 21 & 72.619 & 13.749 & & \\
\hline
\end{tabular}

Firstly, the blood pressure and pulse rate of the selected students were examined, then a lesson entitled "Nitrogen Cycle in Nature" was explained by the same teacher. The students were divided into two groups of 20 students, to provide them with a unified exam. The first group answered the exam in a quiet place, where the noise level was $40 \mathrm{~dB}$ or less and then the student's blood pressure and pulse were recorded. While the second group answered the exam in a noisy place with a noise of $75 \mathrm{~dB}$ and plus, likewise followed by measuring of student's blood pressure and pulse. Finally, exams were marked and the results were analysed to investigate the relationship among noise level, student achievement, their pulse rate and blood pressure as shown in the Table 8.

The results in Table 8 showed that there were a significant statistical differences ( $p$ value $<0.05$ ) between quiet and noisy conditions of the class rooms, when correlated with the student's blood pressure and their academic performance after setting for the exam.

\section{CONCLUSSION}

This study investigated the noise trends and impacts at Gazan preparatory and secondary schools. The highest value of noise was $67.5 \mathrm{~dB}$ and the lowest value was $49 \mathrm{~dB}$. However the average noise level at the secondary male schools was between $(50-65.4) \mathrm{dB}$ while it was around $(49-67.5) \mathrm{dB}$ at the female secondary schools. On the other hand, the average of the noise levels at the male preparatory schools was $58.8-66 \mathrm{~dB}$ while it was $56.2-$ $61.4 \mathrm{~dB}$ at the female preparatory schools.

It was noticed that the noise levels in preparatory schools were higher than secondary schools with a mean of $60.79 \mathrm{~dB}$, which means that noise levels in classrooms and playgrounds across these schools were higher than WHO allowable levels for community learning environments. High noise levels generated due to several factors such as, high class density, hawkers, building shape and school location. Whereas, the class density was the main cause that led to the highest noise levels with a mean of $66.06 \mathrm{~dB}$.

The chronic exposure to noise caused many health problems, this research studied the correlation between exposure to noise, the increase in blood pressure and pulse rate according to gender, grade and average of the students. There was a significant difference ( $p$ - value $<0.05$ ) in Pulse rate before classes started, in females with a mean of $81.6 \mathrm{~dB}$, also there is a significant difference ( $\mathrm{p}$-value $<0.05$ ) in pulse after, to females with an average of $82.6 \mathrm{~dB}$. Whereas, there is a significant difference in systolic blood pressure and diastolic blood pressure before classes to males with $112.7 \mathrm{~dB}$ and $72.1 \mathrm{~dB}$. There was insignificant in the systolic and diastolic blood pressure after classes in all schools. In the other hand, there is a significant differences in the average according to gender to females with an average of $82.8 \mathrm{~dB}$. 
Consequently, there was a significant difference in pulse rate after classes and pulse before to preparatory schools, but the significant in diastolic and systolic blood pressure is to secondary schools. However, in the average of the students the significant is to preparatory schools.

According to the experimental sample, the significant difference in pulse after classes ended to the students who exposed to noise with a mean of $91.7 \mathrm{~dB}$ and the significant difference in the diastolic blood pressure after classes to the student $\mathrm{s}$ that exposed to noise with an average of $75.2 \mathrm{~dB}$.

The following recommendations can be applied to reduce noise at schools environment: schools design should follow the open building style rather than the closed one, classrooms floors should be covered by anti -reflection material of high noise a absorbence and double glass windows should be installed, future school zoning should be planned carefully to avoid congested areas, raising awareness on noise pollution risks and negative impacts on children through media campaigns, planting and grow trees around schools where trees leaves absorbs $25 \%$ from noise vibrations. It was noticed that the noise level was reduced about $3 \mathrm{~dB}$ in every floor higher. So it's better to use the ground floor for administrative purposes.

\section{REFERENCES}

1. Andropoulos, D. B. Pediatric Physiology: How Does it Differ from Adults?, Chapter (Edited by: Mason, K. P. , Pediatric Sedation Outside of the Operating Room. 77-91 (2011).

2. Basrur, S. Health Effects of Noise, City of Toronto ,Community and Neighbourhood Services, Toronto Public Health,Health Promotion and Environment Protection Office (2000).

3. Shield, B. and J. Dockrell. The Effects of Noise on Children at School: a Review.J. Building Acoustics 10, 97-106 (2003).

4. Ministry Of High Education. Annual-educational-statistics 2010- 2012.

5. Enmarker, E. (2004). Noise Annoyance Responses of Middle School Pupils and Teachers. Journal of Environmental Psychology 24, 527-536 (2012).

6. Matheson, S. Noise pollution: non-auditory effects on health British Medical Bulletin 68, 243-257 (2003).

7. Ischemic Heart Disease: A Meta-analysis, Environmental Health Perspectives 110 ,Num. 3,Pages $307-317$

8. Annie Ward, Howard W. Stoker, Mildred Murray-Ward Educational Measurement: Theories and applications, http://books.google.ro/books?id=dWTx7RXc028C. (1996).

9. Ministry Of High Education, Annual-educational-statistics-2012-2013, pages 7,8 (2013).

10. WHO, Hypertenion fact sheet, Department of Sustainable Development and Healthy Environments (2011).

11. Shield, B. and J. Dockrell. External and internal noise surveys of London preparatory schools. Journal of the Acoustical Society of America, 115 (0001-4966), 730-738 (2004).

12. Nandi SS, Dhatrak SV. Occupational noise-induced hearing loss in India.Indian J Occup Environ Med.12, 53-6. doi: 10.4103/0019-5278.43260 (2008).

13. Nandi, S. and Dhatrak,S., Occupational noise-induced hearing loss in India (2008).

14. Kang,J. Urban Sound Environment . London:Taylor and Francis (2006).

15. Ahmad,R. Effect of Noise Pollution on Hearing Threshold,Blood Pressure and Oxygen Concentration in Blood of Workers in the Hospitals in Jenin City Palestine,master thesis, An- Najah National University ,Nablus, West Bank,Palestine (2011). 
16. Richard, E., Cardiovascular Physiology Concepts.2nd edition, Lippincott Williams \& Wilkins pub,93-95 (2005).

17. Berntein,D., Nelson Textbook of Pediatrics,18th ed. Philadelphia,Pa: Saunders Elsevier pub,422 (2007).

18. Aasvang, G. Noise, sleep and poor health: Modeling the relationship between road traffic noise and cardiovascular problems. a Institute of Transport Economics, Norway (2011).

19. Ahmad, R. Blood Pressure and Oxygen Concentration in Bloodof Workers in the Hospitals in Jenin An-Najah National University (2001).

20. AslakFyhri, R. Road traffic noise, sensitivity, annoyance and self-reported health-A structural equation model exercise. nstitute of Transport Economics Gaustadalleen, 21. (2007).

21. Berglund B., Guidelines for community noise. World Health Organisation (1999).

22. Birgitta,T. and Dietrich H. Guidelines for community noise World Health Organization (1999).

23. Carlos Rogério Degrandi Oliveira, G. Occupational Exposure to Noise Pollution in Anesthesiology. Journal of Anesthesiology, 62, 253-261 (2007).

24. CCRMA. ound Pressure, Intensity, and Power. from https://ccrma.stanford.edu/courses/150-2001/SPL.html (2007).

25. Dictionaries,O. decibel.from http://www.oxforddictionaries.com/definition/english/decibel (2013).

26. Dictionary,T. blood pressure. from http://www.thefreedictionary.com/blood + pressure (2010).

27. FIU, F. Mathematics Matters Every Day. from http://web.eng.fiu.edu/mathmatters/m2ed/index.htm (2008).

28. Fooladi1, M. Involuntary and Persistent Environmental Noise Influences Health and Hearing in Beirut, Lebanon. nstitute of Transport Economics Gaustadalleen, 5, (2012).

29. Health, C. Noise Pollution from www.cehn.org (2009).

30. Health, S. Anatomy and Physiology of the Ear. from http://www.lpch.org/DiseaseHealthInfo/HealthLibrary/ent/anatomy.html (2010).

31. hyperphysics. Loudness. from http://hyperphysics.phyastr.gsu.edu/hbase/sound/loud.html (2009).

32. MNT. What Is High Blood Pressure? What Causes High Blood Pressure? , from http://www.medicalnewstoday.com/articles/159283.php (2009).

33. Myvmc. Anatomy of the ear. from http://www.myvmc.com/anatomy/ear/ (2004).

34. Noise, N. NIGHT NOISE GUIDELINES FOR EUROPE World Health Organization (2004).

35. Nunez, D. Cause and Effects of Noise Pollution. University of California (1998).

36. Organization, w. CHILDREN AND NOISE Children's Health and the Environment WHO Training Package for the Health Sector World Health Organization from www.who.int/ceh (2013).

37. Pilkington, F. Informing transport health impact assessment inLondon Institute of Occupational Medicine (2000).

38. Ronald P. and Kinga, J. a Consultant Aerospace Medicine, AH-Mk 1 Systems (Apache), Directorate of Army Aviation, Middle Wallop, UK. University of Texas Medical Branch (2002).

39. Salameh, A. Effects of Occupational Noise Exposure on Blood Pressure, Pulse Rate, and Hearing Threshold Levels of Workers in Selected Industrial Plants in Jenin City, Palestine. An-Najah National University (2005). 
40. SinayJuraja, B. Implementation of auditory and non-auditory effects of noise in the risk assessment process in mechanical engineering. MMaMS (2012).

41. Srspharma. ISCHEMIC HEART DISEASE : CAUSES, SYMPTOMS, PREVENTION \& TREATMENT. from http://www.srspharma.com/ischemic-heartdisease-treatment-causes-symptoms.htm (2010).

42. Tanner, E. Environmental Influence on Student Behavior and Achievement. from http://sdpl.coe.uga.edu/researchabstracts/acoustical.html (1999).

43. UNSW. What is a decibel? , from http://www.animations.physics.unsw.edu.au/jw/dB.htm (2012).

44. Van Kempen, B. Selection and evaluation of exposure-effectrelationships for health impact assessment in the field of noise and health. EEMM (2005).

45. Vijayalakshmi, D. Noise Pollution. Proceedings of the Third International Conference on Environment and Health, 25, 597 - 603 (2003).

46. Alberti, P. THE ANATOMY AND PHYSIOLOGY OF THE EAR AND HEARING. University of Toronto Department of Otolaryngology, from palberti@attglobal.net (2012).

47. WebMD. Hypertension/High Blood Pressure Health Center. from http://www.webmd.com/hypertension-high-blood-pressure/guide/hypertensionsymptoms-high-blood-pressure (2012).

48. Yourdictionary. student achievement from http://www.yourdictionary.com/studentachievement (2008).

49. Ingela Enmarker, Eva Boman, Available online 26 January 2005. Noise annoyance responses of middle school pupils and teachers, Journal of Environmental Psychology 24 527-536 (2004).

50. Neil D. Weinstein, Individual Differences in Reactions to Noise: A Longitudinal Study in a College Dormitory, Journal of Applied Psychology, 63, 4, 458-466 (1987).

51. Lauren M. Ronsse Lily M. Wang, 2010. Effects of Noise from Building Mechanical Systems on Elementary School Student Achievement, Published in ASHRAE Transactions 116, 2 (2010).

52. Paul, S. COSTING THE EARTHguidance for sentencersThe Magistrates' Association is a registered charity, no. 216066.28 Fitzroy Square, London W1T 6DDt. 0207387 2353, f. 0207383 4020www.magistrates-association.org.ukISBN 978-1-905313-81-5 (2009).

53. Alkasim, A. and Abubakar-Sadiq,S. Effect of human activities on noise level measurement of some selected areas of Kano metropolis,Kano State Northern NigeriaDepartment of PhysicsModibbo Adama University of TechnologyP.M.B. 2076, Yola NigeriaNigerian Journal of Physics 21, 2 (2010).

54. Maria, El. Computational Processing and Analysis of Ear Images

55. Dissertation submitted to obtain the Master's degree in Biomedical Engineering (2009).

56. BSc in Biomedical Engineering by the School of Industrial Studies and Management, Polytechnic Institute of Porto.

57. Sam, S. Acoustic Glossary of Terms and Definitions for soundproofing and noise control research, products and materials. from http://allnoisecontrol.com/glossary/index.cfm: (2010).

58. Maranon, R. and Reckelhoff, J. F. Sex and Gender Differences in Control of Blood Pressure, Clin Sci (Lond). 125, 7, 311-318. (2013).

59. Khaksari, M. Mahmoodi, M. Rezvani, M.E. Sajjadi, M.A. Karam, G.A. Hajizadeh, S. Differences between male and female students in cardiovascular and endocrine responses to examination stress. J Ayub Med Coll Abbottabad, 17, 2, 15-9 (2005). 